\title{
Control of Heavy Metal Pollution in Degraded Rural Areas
}

\author{
Ivars Locis \\ Rezekne University of Applied Sciences, Faculty of Engineering \\ Atbrīvošanas aleja 76, Rēzekne, LV 4601, Latvija.e-pasts: haris63@inbox.lv
}

\begin{abstract}
The paper presents the issue of heavy metals in the different types of degraded territory in rural areas. For the test was chosen three different degraded territory: the former petrol station, the former farm mechanical workshop, the former farm cattle storage. All of three objects during operation were subjected to intensive polluting impact. They are included in the contaminated and potentially contaminated sites register. High concentrations of heavy metals in the soil of degraded territory is a factor that affects the planning for regeneration. Revitalization of contaminated sites and further use of them is possible only after the remediation works.
\end{abstract}

Keywords: degraded territory; heavy metals; concentrations.

\section{INTRODUCTION}

Degraded territories are previously used and abandoned sites, the return of the efficient exploitation of them require intervention. Types of degraded territory in rural areas are old agriculture, infrastructure and production facilities whose physical condition over time becoming increasingly worse. They are included in the contaminated and potentially contaminated sites register. In such areas often start to develop spontaneous dumps, and they also become an environmental problem $[1 ; 6]$. Waste dumping may lead to localized, but in the event the spread of pollution, a regional soil, ground and groundwater contamination [4]. Most significant of these pollutants are heavy metals. Heavy metals in soil and in the ground are non-biodegradable. It is possible their migration with downward flows of water. Engaging in chemical and biochemical reactions heavy metals may to form new compounds, which may increase toxicity [2].

Heavy metal naturally concentration in soil is dependent of the bedrock, of soil type and chemical properties of them. Anthropogenic effects may contribute the increase of concentration of heavy metals in comparison with natural background [3]. Soil contamination with heavy metals resulting from fuel combustion and under the influence of motor vehicle. Heavy metals accumulate in the soil, especially in the upper soil layers [7].

To determine soil and ground quality have been developed limits for purpose and values of the more toxic heavy metals concentration. According to the legislative requirements of soil, ground and groundwater conditions there are 3 limit groups:

- "A" value, or purpose value. If pollutant concentrations are above this level, it is impossible to ensure sustainable soil or groundwater quality;

- "B" value, or the prudential limit. It indicates the maximum contamination level above which is possible potential negative effects on human health or the environment, as well as the level to be attained by the contaminated site remediation, if is not indicate stricter requirements for remediation;

- "C" value, or a critical limit. If it reaches or exceeds the soil and ground functional characteristics are seriously impaired by pollution, or pollution directly threatened to human health or the environment [5].

In Rezekne Higher Education Institution is made a complex study "Exploration of regional peculiarities of areas degradation processes and scientific- technical justification of regeneration principles ". This study took place in framework of complex study. The ground contamination is one of the influencing factors of degraded territories revitalization planning; the continued use of contaminated sites is possible only after the remediation works.

\section{Research methods and equipment}

For the study were chosen three objects, which are typical examples of Soviet agricultural infrastructure in rural areas, they was the former gas station, a former farm mechanical workshop (hereafter referred to as Workshop), and the former cattle farm Storage (hereafter referred to as - Storage). In the gas station in 2002nd and 2003th was carried out environmental monitoring. By the data of monitoring object was found to be contaminated. The second object - the Workshop and the third object - Storage are typical examples of rural degraded territories. All of three objects during operation were subjected to intensive polluting impact. They are included in the Latvian contaminated and potentially contaminated sites register. In such a way have been investigated several types of degraded territories. Samples were taken in two depths, $0.25 \mathrm{~m}$ deep and $0.5 \mathrm{~m}$ deep.

\section{Used equipment and work methodology}

Experimentally was set at 8 heavy metals $(\mathrm{Cr}, \mathrm{Cu}$, $\mathrm{Mn}, \mathrm{Sr}, \mathrm{Zn}, \mathrm{Ca}, \mathrm{Fe}, \mathrm{Mg}$ ) concentration in soil samples by inductively coupled plasma optical emission spectrometer Optima 2100 DV ICP / OES. 
The method is based on the measurement of optical emission intensity of metal atoms, which formed by awake of metal atoms with inductively coupled argon plasma energy. Equipment is able to determine metals substance up to $10^{-10} \%$.

Experiments were performed according to standard LVS EN ISO4934: $2004^{\text {th }}$. Samples were dried and crushed to a particle size $<150 \mu \mathrm{m}$, the sample mass for measurement was $1.5 \mathrm{~g}$.

Results were obtained in (mg/ l). To convert the units $(\mathrm{mg} / \mathrm{l})$ per unit $(\mathrm{mg} / \mathrm{kg})$ in calculations using the formula:

$$
C=\frac{C_{e l} \cdot \operatorname{Vpar} \cdot 1000}{m_{k}}(\mathrm{mg} / \mathrm{kg})
$$

Where: $\mathrm{C}_{\mathrm{el}}$ - element concentrations ( $\left.\mathrm{mg} / \mathrm{l}\right)$;

Vpar - volume of sample after mineralization, (l); $\mathrm{m}_{\mathrm{k}}$ - ground mass $(\mathrm{g})$.

\section{RESULTS AND DISCUSSION}

Gas station description. Gas station is located on a small hill with a skid top. It is 1.5 to $5.0 \mathrm{~m}$ above the surrounding territory. The area is 0.5 ha. Gas stations in the east and the north is limited by deep valleys, which about $150 \mathrm{~m}$ from the object connects to the stream that connects several lakes.

Fuel tanks placement area, which was located 4 overground fuel tanks of $10 \mathrm{~m}^{3}$ each, is limited to the bottom rampart 0.3 to $1.0 \mathrm{~m}$ in height.

Economic activities are not carried out since 2004. Since the discontinuation of gas station facilities have been removed, but the buildings are collapsed. Object is included in the contaminated and potentially contaminated sites database of Latvian Environment, Geology and Meteorology Centre, and complying with degraded territories properties.

Soil samples were taken in gas station territory in two locations:

- the fuel tank area, $1^{\text {st }}$ place (Table 1.);

- the petrol pumps area, $2^{\text {nd }}$ place (Table 2.).

TABLE 1

HEAVY METAL CONCENTRATIONS IN $1^{\text {ST }}$ PLACE SAMPLES OF GAS STATION (MG / KG)

\begin{tabular}{|l|l|l|}
\hline The metal & 0.25 m depth & 0.5 m depth \\
\hline $\mathrm{Cr}$ & 0,39 & 0,17 \\
\hline $\mathrm{Mn}$ & 47,32 & 47,15 \\
\hline $\mathrm{Sr}$ & 0,13 & 0,13 \\
\hline $\mathrm{Zn}$ & 4,38 & 4,33 \\
\hline $\mathrm{Ca}$ & 1142,87 & 995,15 \\
\hline $\mathrm{Fe}$ & 343,81 & 302,25 \\
\hline $\mathrm{Mg}$ & 652,90 & 694,07 \\
\hline
\end{tabular}

TABLE 2 .

HEAVY METAL CONCENTRATIONS IN $2^{\text {ND }}$ PLACE SAMPLES OF GAS STATION (MG / KG)

\begin{tabular}{|l|l|l|}
\hline The metal & 0.25 m depth & $0.5 \mathrm{~m}$ depth \\
\hline $\mathrm{Cr}$ & 0,74 & 0,61 \\
\hline $\mathrm{Mn}$ & 46,89 & 46,80 \\
\hline $\mathrm{Sr}$ & 0,22 & 0,17 \\
\hline $\mathrm{Zn}$ & 4,68 & 4,46 \\
\hline $\mathrm{Ca}$ & 1248,13 & 1199,64 \\
\hline $\mathrm{Fe}$ & 357,72 & 364,10 \\
\hline $\mathrm{Mg}$ & 523,25 & 565,80 \\
\hline
\end{tabular}

In ground granulometric composition inspection found that the gas station samples consist of sandy loam with gravel and organic particulate impurity from the plant roots. Analysis of soil samples from the gas station site, concentrations of heavy metals in excess of the target value of $\mathrm{A}$, was not detected.

Workshop description. The area is 2.8 ha. Workshop in the east and north is restricted to the deep ravine which connects to the west creek that runs about $100 \mathrm{~m}$ from the object, which connects several lakes. Soil samples were collected in Workshop territory in two locations:

- repairable technical area $1^{\text {st }}$ place (table 3.$)$;

- equipment storage area $2^{\text {nd }}$ place (table 4.).

TABLE 3.

HEAVY METAL CONCENTRATIONS IN $1^{\text {ST }}$ PLACE SAMPLES OF WORKSHOP (MG/KG)

\begin{tabular}{|l|l|l|}
\hline The metal & 0.25 m depth & 0.5 m depth \\
\hline $\mathrm{Cr}$ & 4,16 & 3,51 \\
\hline $\mathrm{Cu}$ & 1,65 & 1,43 \\
\hline $\mathrm{Mn}$ & 130,35 & 127,23 \\
\hline $\mathrm{Sr}$ & 0,95 & 0,82 \\
\hline $\mathrm{Zn}$ & 5,07 & 4,85 \\
\hline $\mathrm{Ca}$ & 2406,43 & 2353,61 \\
\hline $\mathrm{Fe}$ & 2852,81 & 2611,87 \\
\hline $\mathrm{Mg}$ & 1665,99 & 1747,07 \\
\hline
\end{tabular}

TABLE 4.

HEAVY METAL CONCENTRATIONS IN $2^{\text {ND }}$ PLACE SAMPLES OF WORKSHOP $(\mathrm{MG} / \mathrm{KG})$

\begin{tabular}{|l|l|l|}
\hline The metal & 0.25 m depth & 0.5 m depth \\
\hline $\mathrm{Cr}$ & 3,47 & 2,77 \\
\hline $\mathrm{Cu}$ & 1,26 & 1,04 \\
\hline $\mathrm{Mn}$ & 121,94 & 117,56 \\
\hline $\mathrm{Sr}$ & 0,61 & 0,39 \\
\hline $\mathrm{Zn}$ & 4,81 & 4,72 \\
\hline $\mathrm{Ca}$ & 2260,87 & 2152,97 \\
\hline $\mathrm{Fe}$ & 2484,78 & 2392,61 \\
\hline $\mathrm{Mg}$ & 1629,85 & 1595,19 \\
\hline
\end{tabular}


In ground granulometric composition inspection found that the workshop samples consist of sandy loam, gravel, dolomite shivers mixture and organic contaminants from the plant roots. Analysis of soil samples from the site workshop, heavy metal concentrations in excess of the target value of $\mathrm{A}$, was not detected.

Storage description. The area is 8.7 ha. Storage is located on the hill with poor natural drainage to the east and south, which is restricted to the deep valley where there is excavated drainage ditch which about $250 \mathrm{~m}$ from the object flows into a stream that flows into the river and then flows into the lake.

The object is partially destroyed, in the area begins to form spontaneous construction waste and municipal solid waste landfill site.

Soil samples were taken into a storage area in three places:

near the entrance to the feed warehouse, $1^{\text {st }}$ place (table 5.);

next to the object's internal road, $2^{\text {nd }}$ place (table 6.); near the entrance to the housing of livestock, $3^{\text {rd }}$ place (table 7.).

TABLE 5.

HEAVY METAL CONCENTRATIONS IN $1^{\text {ST }}$ PLACE SAMPLES OF STORAGE $(\mathrm{MG} / \mathrm{KG})$

\begin{tabular}{|l|l|l|}
\hline The metal & 0.25 m depth & 0.5 m depth \\
\hline $\mathrm{Cr}$ & 3,03 & 2,64 \\
\hline $\mathrm{Cu}$ & 0,87 & 0,52 \\
\hline $\mathrm{Mn}$ & 49,40 & 48,14 \\
\hline $\mathrm{Sr}$ & 0,43 & 0,39 \\
\hline $\mathrm{Zn}$ & 6,07 & 5,94 \\
\hline $\mathrm{Ca}$ & 1040,00 & 1045,55 \\
\hline $\mathrm{Fe}$ & 2457,43 & 2330,64 \\
\hline $\mathrm{Mg}$ & 948,13 & 825,80 \\
\hline
\end{tabular}

TABLE 6.

HEAVY METAL CONCENTRATIONS IN $2^{\text {ND }}$ PLACE SAMPLES OF STORAGE $(\mathrm{MG} / \mathrm{KG})$

\begin{tabular}{|l|l|l|}
\hline The metal & 0.25 m depth & $0.5 \mathrm{~m}$ depth \\
\hline $\mathrm{Cr}$ & 1,82 & 1,73 \\
\hline $\mathrm{Cu}$ & 0,39 & 0,30 \\
\hline $\mathrm{Mn}$ & 48,58 & 48,27 \\
\hline $\mathrm{Sr}$ & 0,30 & 0,26 \\
\hline $\mathrm{Zn}$ & 4,94 & 5,98 \\
\hline $\mathrm{Ca}$ & 1026,05 & 994,15 \\
\hline $\mathrm{Fe}$ & 1886,78 & 1745,16 \\
\hline $\mathrm{Mg}$ & 926,08 & 924,43 \\
\hline
\end{tabular}

TABLE 7.

HEAVY METAL CONCENTRATIONS IN $3^{\text {RD }}$ PLACE SAMPLES OF STORAGE $(\mathrm{MG} / \mathrm{KG})$

\begin{tabular}{|l|l|l|}
\hline The metal & $0.25 \mathrm{~m}$ depth & $0.5 \mathrm{~m}$ depth \\
\hline $\mathrm{Cr}$ & 1,60 & 1,43 \\
\hline $\mathrm{Cu}$ & 0,26 & 0,22 \\
\hline $\mathrm{Mn}$ & 48,01 & 48,06 \\
\hline $\mathrm{Sr}$ & 0,30 & 0,17 \\
\hline $\mathrm{Zn}$ & 6,24 & 5,81 \\
\hline $\mathrm{Ca}$ & 1138,71 & 1123,24 \\
\hline $\mathrm{Fe}$ & 1660,19 & 1532,44 \\
\hline $\mathrm{Mg}$ & 800,45 & 839,54 \\
\hline
\end{tabular}

In ground granulometric composition inspection found that the storage samples consist of clay with gravel and dolomite shivers impurities. In the level upper $0.25 \mathrm{~m}$ a lot of the roots. Analysis of soil samples from the storage the heavy metal concentrations in excess of the target value of $\mathrm{A}$, was not detected.

Comparing the the heavy metal concentrations in studied soil samples shows that $85.7 \%$ of the measurements of heavy metal concentrations increased depth decreases. This is explained by soil filtration ability, which is different for different soil types. Exception is mainly composed of $\mathrm{Mg}$ concentration ratio that in 4 cases in $0.25 \mathrm{~m}$ depth is less than in $0.5 \mathrm{~m}$ depth. This can be explained to the high consumption of $\mathrm{Mg}$ in plants. This can lead to increased $\mathrm{Mg}$ migration from the soil and the top soil layers. Assessing the soil sample results can be concluded that the concentration of heavy metals in tested soil samples are not exceeding the maximum natural concentration.

Storage soil analysis results in comparison with results of GAS and Workshop soil analysis results show that the concentrations of heavy metals there are more than in the samples of gas station and lower than in the samples of workshop, although there is no economic activity within the storage area for twenty years. This can be explained to the fact that:

The slope of storage terrain is insignificant, which complicates rainwater draining and flushing of the upper layers of soil;

The upper soil layers make up clay - soil with low filtration coefficient, which prevents surface water leaching into deeper soil layers, providing filtering pollutants from the upper soil layers to deeper.

Assessing the results of soil sample analysis in facilities GAS and workshop can be concluded that over time the upper soil layers are cleansed naturally. Factors that contribute to cleansing are:

Topography of area;

Geological structure of the territory.

GAS and workshop areas has a natural inclination towards the southeast, south, it provides a natural rainwater runoff from the area by promoting the potential leaching of pollutants from the upper soil layers. 
Workshop area observed a higher concentration of heavy metals than the GAS area, but it does not exceed the maximum allowed natural concentrations.

$\mathrm{Ca}, \mathrm{Fe}, \mathrm{Mg}$, is one of the constituent elements of rocks, it sets it relatively high concentration in soil samples. Another reason for the high concentration of this element is the presence of dolomite shiver in workshop and storage soils. Dolomite is composed of magnesium and calcium carbonate. In comparison with gas station where the ground is composed of natural elements - sand with contamination, in sampling sites of workshop completely but in storage partially the upper layer of ground in sampling depth is composed of an artificial gravel and dolomite shiver mixture. Mn in Earth's crust is in second place after Fe in heavy metals prevalence. In tissues of plant and animal, it is present as a trace element. In the soil it comes from plants, as well as the fuel and combustion products. $\mathrm{Sr}$ is one of the constituent elements of the micro-organisms, plants and animals, its concentration in ground samples may be associated with plant metabolism. $\mathrm{Cr}, \mathrm{Cu}$ and $\mathrm{Zn}$ concentrations were determined in all soil samples. Limit values were not exceeded in none of samples.

\section{CONCLUSIONS}

By conducting a study led to the following conclusions:
1. Concentrations of heavy metals in the soil of studied objects do not exceed the target values.

2. Natural concentration of heavy metals in the soil is dependent on the bedrock, where samples were taken, from type and chemical properties of the soil.

3. Ground which is contaminated through the economic use over the years can clean itself of heavy metal contamination.

4. Objects GAS and workshop areas are ground geological structure, which is composed of different fractions of sand and loamy sand provides high filtration coefficient for the upper layers of ground that allow pollutants to flow through the upper ground layers and come into the deeper ground layers.

\section{REFERENCES AND SOURCES}

[1] Degradētās teritorijas. Rokasgrāmata. Redaktors B. Voijvodikova, Rēzekne: SIA Latgales Druka, 2010. 140 lpp.

[2] Kḷavinšs M. Vides piesārṇojums un tā iedarbība. Rīga: LU Akadēmiskais apgāds, 2009. 198 lpp.

[3] Mirsal I. A. Soil pollution. Origin, monitoring \& remediation. Berlin: Springer - Verlag Berlin Heidelberg, 2004. 252 p.

[4] Vide un ilgtspējīga attīstība. Redaktori Klavinšs M., Zaḷoksnis J. Rīga: LU Akadēmiskais apgāds, 2010. 334 lpp.

[5] Noteikumi par augsnes un grunts kvalitātes normatīviem. LR Ministru kabineta noteikumi Nr.804, 25.10.2005.

[6] Noviks G., Teirumnieks E., Lemešonoka N., Matisovs I., Teirumnieka E. ., Miklaševičs Z. Evaluation of brownfields in Latvia. Rēzekne: Proceedings of the 7th international scientific and practical conference, 2009

[7] Мотузова Г. В., Безуглова О. С. Экологический мониторинг почв. М: Академический проект Гаудеамус, 2007. $237 \mathrm{c}$ 